\title{
The Marital Compatibility of Married Students in Jordan's Private Universities Located in the Northern Region, and Its Relation to Some Variables
}

\author{
Salem Harahsheh ${ }^{1}$ \\ ${ }^{1}$ Department of Educational and Psychological Counseling, College of Educational Sciences, Irbid National \\ University, Irbid, Jordan \\ Correspondence: Salem Harahsheh. E-mail: salemhmood58@yahoo.com
}

Received: December 16, 2020

Accepted: December 19, 2020

Online Published: December 30, 2020

doi:10.5539/ass.v17n1p118

URL: https://doi.org/10.5539/ass.v17n1p118

\begin{abstract}
The study aimed at identifying the degree of marital compatibility of married students in the Jordanian private universities located in Jordan's northern region and its relation with some variables, the sample of the study consisted of (293) married students. The study has applied the relational descriptive approach. The results showed that the degree of marital compatibility was positive and moderate, the presence of a negative correlation ship between marital compatibility and accumulative average, and statistically significant differences according to gender variable in favor of females. On the other hand, there were no statistically significant differences according to variables of family numbers, monthly income, and marriage period, with an emphasis on conducting and holding training workshops to enhance marital compatibility among students.
\end{abstract}

Keywords: marital compatibility, married students, private universities, Jordan

\section{Introduction}

\section{1}

Marriage is a pattern of human life, and it is considered one of the most crucial legal and social systems between both genders, in which the integrity of social conditions, the survival of the gender, and the transcendence of relations between males and females.

Considering marriage as a basic factor for growth, its elements should be fulfilled to achieve happiness, because the failure in fulfilling these elements causes a sort of misery in life and lifetime conflicts (Minnotte, 2004). To achieve the aims of marriage, the two partners should be consistent, aware of real concepts for marital life, and working together to build a cohesive, happy life (Al-khtabyah, 2015).

It should be noted that marital life would not be completed unless both partners fully perform rights and duties, whether moral or material, which will end with a happy life that helps fulfill many marital needs based on mutual coexistence, love, and appreciation (Al-Jam'an, 2018). Accordingly, the family characterized by parents is responsible for raising their children, keeping the communication among its individuals, and build the basics of several ways that achieve compatibility in social, entertaining, financial activities and what it includes in terms of determining methods and fields of spending (Kalhout, 2011).

Studies confirm that a positive marital relationship results from personal happiness and that the more compatible husbands are, the more they can face different difficulties (Mahmoud, 2006).

Suppose this relationship is based on robust and harmonious ties, dominated by calm, contentment, and cohesion. In that case, it will pass through crises of tension in a short time, in contrast to whether the relationship is dominated by turmoil and emotion, which will lead to disintegration and its reflection on raising children (Suliman, 2004).

Marriage, through its early stages, includes enthusiasm, attractiveness, and tolerance. Whereas, with the passage of time and the subsequent stages it contains, the relationship becomes more confrontational, and an atmosphere of dialogue, debate, and negotiation prevails and is related to defining the roles and responsibilities for each of them (Suleiman, 2005, p. 18). 
Familial security considered as one of the basic constituents of individuals' life, and the goal of every family, along with its role that's characterized in protecting this family from disintegration, represented by separation or divorce, considering the negative consequences that result from it, which affect family members and society; since their affection is mutual (Al-husny, 2016). The more personal characteristics between husband and wife were homogeneous, physically, mentally, psychologically, and socially, the more they're adapted to their marital life (Al-Soghair, 2014; Suleiman, 2005).

Furthermore, studies showed that emotional compatibility between husband and wife helps increase marital happiness, whereas a lack of emotions causes a decreasing level of marital happiness (Peleg, 2008). Studies showed that factors like education level and income affect marital compatibility, where the results were in favor of high education level like master's degree and, likewise, people with high income and salaries (El-Khatiba, 2015). Besides, the wife's job as an effective factor, and what does it impose in terms of psychological, physical, and social burdens and pressures, which reduce marriage quality and stability? (Presser, 2000) Moreover, the nature of stress and pressure is related to the number of children in the family (Sussman \& Steinmetz, 2013). As Al-Dahri (2008) concluded, if the number of children exceeds (7), it will negatively affect marital compatibility.

\subsection{The Study Problem}

Recently, some difficulties have emerged that have increased burdens on the Jordanian families and created many pressures upon them, and among these aspects were: the multiplicity of social roles for the spouses, and the exacerbation of financial burdens, as a result of the increase of these pressures, problems of husbands have exacerbated and affected family life in general, and leads to adverse effects on the marital compatibility. So, knowing ourselves, our expectations, to our ability act in a specific manner, and understanding each other contributes to keeping the continuity and permanence of a successful marital life, as married students in Jordan in general and the northern region, in particular, are exposed to many different pressures which differ according to their life circumstances.

Females among married students face many challenges, such as family responsibilities and university requirements. Her obligations grow and multiply between being a wife and a student simultaneously, as it is challenging to balance home and university. Her role and responsibilities vary between child custody, taking care of her house, feeding her family, protecting them, and following up on the children's school status. Her pressures do not end up here, but also family disputes, which may negatively affect her academic performance, and thus self-efficacy begins to decline, which leads to a decrease in study incentive that may result in poor grades and thus failure in the study. Hence, the current study reveals the degree of marital compatibility among married students in private universities in the Northern Region in Jordan and its relationship to some variables. Hence the current study attempts to answer the following questions:

$>$ What is the degree of marital compatibility among married students in the private universities of the Northern Region?

$>$ What is the degree of the relationship between the level of marital compatibility and the student's Accumulative average?

$>$ Are there statistically significant differences in the level of marital compatibility among students due to the gender variable (males, females)?

$>$ Are there statistically significant differences in the degree of marital compatibility due to the variable of the number of family members?

$>$ Are there statistically significant differences in the degree of marital compatibility due to the variable of monthly income?

$>$ Are there statistically significant differences in the degree of marital compatibility attributed to the duration of marriage?

\subsection{Objectives of the Study}

The study sought to achieve a set of goals as follows:

$>$ Identify the degree of marital compatibility among married students in the private universities of the northern region.

> Identify the relationship between the level of marital compatibility and the student's Accumulative average.

$>$ Discover the differences in marital compatibility levels among students according to the variables; gender, the number of family members, monthly income, and the duration of the marriage. 


\subsection{The Importance of the Study}

The issue of marital compatibility is critical, as it deals with an individual and social issue because of the information it provides that contributes to discovering the degree of marital compatibility and happiness, especially after the increasing rates of divorce, violence, and family disintegration in Jordan, and the high level of domestic violence. Therefore, this study comes to clarify many variables related to marital compatibility, which helps us in guiding those who suffer from incompatibility in marital life, whether they are married or who wish to marry, and what helps the official authorities represented by the Supreme Judge Department, universities, and specialists in designing programs, holding workshops, and courses, and reaching to guidance methods that deals with reducing the phenomenon of divorce and family disintegration, which contributes to creating a positive environment that helps husbands and children to grow and prosper. The researcher hopes to enrich a scientific addition to the Jordanian library's knowledge and those interested concerning marital compatibility among married students and those in school.

Furthermore, the importance of this study relies in its originality in the Jordanian society, which deals with marital compatibility for married students who are still studying, and the scarcity of studies that specifically deal with marital compatibility and its relationship to academic achievement (according to the researcher's knowledge), and the study of marital compatibility and its relationship to work variables, and the number of family members, and the consequent increase in burdens and pressures resulting from the requirements of academic study, the completion of the required career work, and the ability to meet the needs of children and family members. This study can be a source and reference in directing researchers to pay attention to later studies. This results from the results of this study of conclusions and recommendations.

\subsection{Scope of the Study}

The scope of applying the present study is determined by the following:

> Time limit: The study was applied during the summer semester of the 2019/2020 academic year.

$>$ Place limit: the private universities of the northern region in Jordan.

$>$ Study sample: married students in private universities.

$>$ Objective limits: The study results are determined by the study tools in which they were used and the indications of validity and reliability that they have. Therefore, the possibility of generalizing the study results to communities similar to the study community is determined only by the extent to which the sample represents its community.

\subsection{Study Variables}

The study included the following variables:

> Marital compatibility: It has five dimensions (psychological compatibility, social compatibility, financial compatibility, compatibility with children, and family problems).

$>$ Gender: It has two categories (male and female).

$>$ Family members: It has three categories (less than 4 members, from 4-6 members, more than 7 members)

$>$ Monthly income: It has three categories (less than 220 dinars, 221-500 dinars, more than 500 dinars).

$>$ ACCUMULATIVE AVERAGE: It has four categories (Acceptable, Good, Very Good, Excellent).

$>$ Duration of marriage: It has three categories (less than 4 years, 4-7 years, 7 years, and more).

\subsection{Conventional and Procedural Definitions}

As defined by Al-Dahri (2008), compassion is a continuous process by which the individual tries to change his behavior to achieve compatibility with the surrounding environment to reach a state of psychological stability and social adjustment (Al-Dahri, 2008, p. 79).

\subsubsection{Psychological Compatibility}

Khalil $(1999 ; 46)$ believes that psychological compatibility is a state of happiness, harmony, and ability to fulfill innate needs and face problems and convergence in the individual's psychological characteristics and inner mood.

\subsubsection{Social Compatibility}

Social interaction is considered a process by which members of society relate to each other, mentally, emotionally, socially, financially, and morally, so that each of them is satisfied with the behavior of the other in a 
general behavioral context acceptable to the group and individuals (Nasser, 2011; 102).

\subsubsection{Marital Compatibility}

Marital compatibility is defined as the adaptation of the husband and wife in a way that allows each of them to avoid conflicts and feel satisfied with each other (Chen et al., 2007). It is also defined as the degree obtained by examining the measure of marital compatibility used in this study.

\section{Literature Review}

This part includes Arab and foreign studies and research related to the research topic, which the researcher sought to discover, take benefit from, and identify the most important results he has reached that may be useful to enrich the current research.

Abbas and Fateel (2019) conducted a study to identify the level of psychological compatibility among students of Irbid National University in the Kingdom of Bahrain and its relationship to some variables. It was applied to a sample of 121 male and female students. The results of the study showed that national University students possess a medium level of psychological compatibility. It also showed no statistically significant differences attributed to the gender variable and the existence of statistically significant differences attributed to the total rate variable in favor of the high rates.

Al-Khateebah (2015) conducted a study to identify the elements of marital compatibility of husbands working in public schools in northern Jordan. The study sample included (388) husband and wife. The study found that the degree of marital compatibility among males is higher than that of females. In contrast, the study showed a lack of happiness among husbands with their wives' performance in terms of compatibility, and the essential elements of marital compatibility were related to preserving romance and maintaining religious behaviors, mutual understanding needs. On the other hand, the results of the study did not show any differences. It is attributed to the variables of gender and family size, while there were differences attributed to the variables of educational level and high income; and it was in favor of high qualification like masters and those who have high income and salaries.

Tawfiq's study (2015) aimed to identify the characteristics of positive social behavior related to marital compatibility and the differences between husbands and wives concerning aspects of positive social behavior. The study sample consisted of (100) husband and wife, with an average age of the husbands (38.10) and an average age of wives (31.09). The study found a statistically significant correlation between marital compatibility and positive social behavior related to tolerance, optimism, positive efficacy, and social sovereignty. The results also showed that no significant differences were found between husbands and wives.

In Parmer's study (2014), which aimed to determine the marital compatibility of a sample of working and non-working women in India, the study sample consisted of (60) working and non-working women. The study results showed that marital compatibility among the sample of non-working women was higher and statistically significant compared to its levels among working women.

The study of Sahu and Sing (2014) aimed at identifying the level of psychological health and marital adjustment of working and non-working women, where the study sample consisted of (200) women. The study results showed that the level of psychological health and marital compatibility was high, and there were no statistically significant differences in the health and marital compatibility between working and non-working married women.

Al-Sharman (2007) conducted a study to reveal the degree of marital compatibility according to the point of view of employees in administrative positions at Yarmouk University. The study sample consisted of (364) spouses. According to the results, the degree of marital compatibility was high in all fields; where the economic field had the first place and the psychological and emotional field came in second place, then the social field.

Sing Thind \& Jaswal (2006) conducted a study to identify the level of marital compatibility and its relation to the employment and education level of the wife. The study sample consisted of (300) spouses. The results showed that wives with high-level positions and education have a high level of marital compatibility, whereas illiterate wives who belong to the third level were more compatible than the first level (high education) and the second level of wives (university).

In the study of Al-Amoudi (2001), he aimed to investigate marital compatibility and its relation to self-affirmation and its connection with some variables among married people in the Holy Makkah Region (gender, educational level, monthly income, number of children, duration of the marriage; the study sample consisted of (440) husband and wife. The study results found that there are statistically significant differences in 
marital compatibility attributed to the variable of gender and in favor of males. There are statistically significant differences in marital compatibility attributed to the children's variable and were in favor of having children in the family. It also found statistically significant differences in marital compatibility in favor of marriage duration while there were no statistically significant differences in marital compatibility regarding the variables like age; when they married, monthly income, and educational level.

The study of El-Desouki (1986) aimed to identify some of the variables related to marriage compatibility, represented by the number of children, the age of marriage, the level of education, the marriage duration, and personal characteristics. The study sample consisted of (90) couples. The results showed statistically significant differences in marital compatibility among those who were married before or after 25 years, but good results favored those who married after 25 years; marital compatibility is also affected by the number of children and the duration of the marriage.

\section{Study Methodology and Procedures}

The current study adopted the correlational descriptive approach since it's the most appropriate for this study's objectives. This approach examines the marital compatibility of married students and their relation to the accumulative average. It also examines the differences between both genders, the number of family members, the duration of the marriage, and the monthly income.

\subsection{The Study Population}

The study population consists of all married couples who are studying in private universities in the North.

\subsection{The Study Sample}

The sample was chosen by the stratified random method by analyzing the original population of the study sample, searching for the characteristics and proportions of each property in this population, and then random selection based on the characteristics of the original community. The number of the sample members reached about (293) married male and female students, as clarified in Table 1.

Table 1. Distribution of study sample individuals according to the study variables

\begin{tabular}{|c|c|c|c|}
\hline Variables & Gender & Redundancy & percentage \\
\hline \multirow{3}{*}{ Gender } & Male & 95 & $32.4 \%$ \\
\hline & Female & 198 & $67.6 \%$ \\
\hline & Total & 293 & $100 \%$ \\
\hline \multirow{3}{*}{ Number of family members } & Less than 4 & 180 & $61.4 \%$ \\
\hline & $4-6$ & 82 & $28 \%$ \\
\hline & Total & 293 & $100 \%$ \\
\hline \multirow{5}{*}{ Accumulative average } & Accepted & -- & -- \\
\hline & Good & 43 & $\% 14.6$ \\
\hline & Very good & 164 & $\% 56$ \\
\hline & Excellent & 86 & 29.4 \\
\hline & Total & 293 & $\% 100$ \\
\hline \multirow{4}{*}{ Monthly income } & Less than 220 & 87 & \\
\hline & $221-500$ & 87 & $\% 29.6$ \\
\hline & More than 500 & 120 & $\% 41$ \\
\hline & Total & 86 & $\% 29.4$ \\
\hline \multirow{4}{*}{ Duration of marriage } & Less than 4 years & 104 & $\% 35.5$ \\
\hline & $4-7$ years & 52 & $\% 17.7$ \\
\hline & 7 years and more & 137 & $\% 46.8$ \\
\hline & Total & 293 & $\% 100$ \\
\hline
\end{tabular}

\subsection{The Study Tool}

The researcher used the questionnaire as a tool to collect data after reviewing the studies and researches, and the tool included (38) statement distributed on the dimensions of psychological compatibility, social compatibility, financial compatibility, compatibility with children, and family conflicts, where all the statements of the tool were formulated to reflect the degree of compatibility and compatibility of married couples. 


\subsubsection{The Validity of the Tool}

The tool was presented to several arbitrators and specialists to ensure the validity; those who are well interested and expert in this study know their opinions regarding its suitability for the purpose that was prepared for. In light of their observations related to the language, the extent to which the statements belong to their domains, and their clarity, some omissions and additions were made until statements are in their last edition (39). The researcher also conducted the validation of construction by applying the scale on an exploratory sample consisting of (39) married male and female students and calculating corrected correlation coefficients for the statements of each dimension. Table 2 shows the fixed correlation coefficients' values for each dimension of the marital compatibility scale.

Table 2. The values of the coefficients of correlation of the marital compatibility scale statement with the dimension to which they belong

\begin{tabular}{|c|c|c|c|c|c|c|c|c|c|}
\hline \multicolumn{2}{|c|}{ Personal compatibility } & \multicolumn{2}{|c|}{ Social compatibility } & \multicolumn{2}{|c|}{ Financial compatibility } & \multicolumn{2}{|c|}{$\begin{array}{l}\text { Compatibility with } \\
\text { children }\end{array}$} & \multicolumn{2}{|c|}{ Familial conflicts } \\
\hline $\begin{array}{l}\text { Statement } \\
\text { number }\end{array}$ & $\begin{array}{c}\text { coefficients } \\
\text { of } \\
\text { correlation }\end{array}$ & $\begin{array}{l}\text { Statement } \\
\text { number }\end{array}$ & $\begin{array}{c}\text { coefficients } \\
\text { of } \\
\text { correlation }\end{array}$ & $\begin{array}{l}\text { Statement } \\
\text { number }\end{array}$ & $\begin{array}{c}\text { coefficients } \\
\text { of } \\
\text { correlation }\end{array}$ & $\begin{array}{l}\text { Statement } \\
\text { number }\end{array}$ & $\begin{array}{l}\text { coefficients } \\
\text { of } \\
\text { correlation }\end{array}$ & $\begin{array}{l}\text { Statement } \\
\text { number }\end{array}$ & $\begin{array}{c}\text { coefficients } \\
\text { of } \\
\text { correlation }\end{array}$ \\
\hline 1 & $* 0.59$ & 12 & $* 0.55$ & 18 & $* 0.40$ & 24 & $* 0.45$ & 32 & $* 0.71$ \\
\hline 2 & $* 0.78$ & 13 & $* 0.43$ & 19 & $* 0.73$ & 25 & $* 0.45$ & 33 & $* 0.63$ \\
\hline 3 & $* 0.61$ & 14 & $* 0.58$ & 20 & $* 0.46$ & 26 & $* 0.53$ & 34 & $* 0.61$ \\
\hline 4 & $* 0.49$ & 15 & $* 0.60$ & 21 & $* 0.55$ & 27 & $* 0.36$ & 35 & $* 0.67$ \\
\hline 5 & $* 0.75$ & 16 & $* 0.34$ & 22 & $* 0.73$ & 28 & $* 0.53$ & 36 & $* 0.64$ \\
\hline 6 & $* 0.63$ & 17 & $* 0.49$ & 23 & $* 0.43$ & 29 & $* 0.67$ & 37 & $* 0.60$ \\
\hline 7 & $* 0.76$ & & & & & 30 & $* 0.73$ & 38 & $* 0.57$ \\
\hline 8 & $* 0.50$ & & & & & 31 & $* 0.62$ & & \\
\hline 9 & $* 0.76$ & & & & & & & & \\
\hline 10 & $* 0.71$ & & & & & & & & \\
\hline 11 & $* 0.60$ & & & & & & & & \\
\hline
\end{tabular}

* Significance at the level of 0.01

It is noticed from Table 2 that the values of the statement's correlation coefficients of the personal compatibility dimension ranged between (0.49-0.78), while the social compatibility dimension ranged between (0.34-0.60), and in the financial compatibility dimension, the values of the statement's correlation coefficients ranged between (0.40-0.73). As for the dimension of compatibility with children, the statement correlation coefficients ranged between (0.36-0.73). Finally, the dimension of family problems ranged between (0.57-0.71). The correlation coefficients for the total scale ranged between $(0.340 .78)$, all of which are statistically significant values, at the level of significance 0.01

\subsubsection{The Reliability of the Tool}

\section{Cronbach Alpha Method}

To verify the tool's reliability, the researcher calculated the reliability coefficient using the internal consistency method according to the Cronbach Alpha equation, as it's clarified in the table below.

Table 3. Stability coefficient (Cronbach alpha method)

\begin{tabular}{ccccccc}
\hline $\begin{array}{c}\text { Personal } \\
\text { compatibility }\end{array}$ & $\begin{array}{c}\text { Social } \\
\text { compatibility }\end{array}$ & $\begin{array}{c}\text { Financial } \\
\text { compatibility }\end{array}$ & $\begin{array}{c}\text { Compatibility } \\
\text { with children }\end{array}$ & $\begin{array}{c}\text { Familial } \\
\text { conflicts }\end{array}$ & $\begin{array}{c}\text { Personal } \\
\text { compatibility }\end{array}$ & $\begin{array}{c}\text { All } \\
\text { dimensions }\end{array}$ \\
\hline $\begin{array}{c}\text { Statements } \\
\begin{array}{c}\text { Alpha } \\
\text { coefficient }\end{array}\end{array}$ & $* 0.91$ & 6 & 6 & 8 & 7 & 38 \\
\end{tabular}

* Significant at the level of 0.01

As shown in Table 3, the reliability coefficients for each field and the overall degree of the scale are high, and the value of the total stability coefficient for the instrument expressions is $(0.97 *)$. These values indicate the validity of the tool for application and the possibility of reliance on the research results and verification.

2. Halftone segmentation method:

Pearson correlation coefficient was found between the degree of single-rank statements and even-rank statements 
for each dimension, and the correlation coefficients were corrected using the Spearman-Brown Coefficient correlation coefficient according to the equation: reliability coefficient $=\frac{R 2}{R+1}$

Considering that $(\mathrm{R})$ the correlation coefficient and Table 4 show a relatively large coefficient of stability for the two scales' items.

Table 4. Coefficient of stability (half segmentation method)

\begin{tabular}{lcccc}
\hline & Dimension & statements & Coefficient of stability & The Correcting Coefficient of stability \\
\hline 1 & Personal compatibility & 11 & $* 0.88$ & $* 0.94$ \\
2 & Social compatibility & 6 & $* 0.74$ & $* 0.85$ \\
3 & Financial compatibility & 6 & $* 0.68$ & $* 0.81$ \\
4 & Compatibility with children & 8 & $* 0.72$ & $* 0.84$ \\
5 & Family conflicts & 7 & $* 0.69$ & $* 0.82$ \\
6 & All dimensions & 38 & $* 0.96$ & $* 0.96$ \\
\hline
\end{tabular}

* Significant at the level of 0.01

Scale correction:

The marital compatibility scale includes (38) items in its current final form, to which it is answered with a quadruple scale that includes alternatives; (rarely) given when correcting the scale one degree; (Sometimes) given when correcting a scale two degrees; (Mostly) three scores, (always) four scores when corrected. Thus, the degrees of the overall scale ranged between (38-152). The dimensions were as follows: personal compatibility (11-44), social compatibility (6-24), financial compatibility (6-24), compatibility with children (8-32). And the dimension of family problems (7-28), where the higher the score, the higher the marital compatibility was.

Procedures:

The study tool was prepared in its final form after verifying its validity and reliability indicators and distributing it to married students in private universities in May/ 2020 through an electronic questionnaire on Google Drive. The respondents took (8) days to answer them, and they were assured that their participation is voluntary and that the data they will provide will be treated with complete confidentiality and will be used for scientific research purposes. After conducting the exploratory study, we found that the time taken by the survey sample members in their responses to the scale ranged between (30-45) minutes, and the answers were uploaded from the site to the SPSS program, then we applied the appropriate statistical treatments according to the (SPSS) program to answer the study questions.

\subsection{Data Analysis}

The averages and standard deviations were used in this study, where the t-test for gender differences and Pearson correlation coefficient were used to determine the relationship between marital compatibility and the ACCUMULATIVE AVERAGE. One Way ANOVA was used to determine differences in family members' variables, monthly income, and duration of the marriage.

\section{Results of the Study}

The results of each question that the study tried to answer are as follows:

The first question: what is the degree of marital compatibility for married students in Universities?

To answer this question, the arithmetic averages, standard deviations, and the relative weight of the marital compatibility level were extracted, which were discussed as follows:

First: Display the dimensions in descending order.

Second: Presenting the statements according to the fields in descending order.

In light of the progressive scale of the study tool represented by the Marital Compatibility Questionnaire, and based on many previous studies (Abbas \& Fateel, 2019; Harahsheh, 2019; Al-Naji, 1995) and consulting many specialists in measurement and evaluation, and to reveal the degree of marital compatibility among married students in private universities in the analysis of the fields and statements of the study, the researcher relied on considering that if the relative weight is less than $(0.50 \%)$, It's considered low. If it ranges between $(0.50 \%)$ and less than $(70 \%)$, it is considered medium, and if it exceeds $(0.70 \%)$ it is considered high.

First: Presenting the fields of study by extracting the arithmetic means and the relative weight in descending order, as it's shown in Table 5. 
Obviously, according to Table 5 that the level of all fields ranged between $(57.75-62 \%)$, all of which came with a moderate degree of compatibility, where the first dimension of "personal compatibility" came in first place with relative weight (62\%), while the third dimension came. Financial compatibility "ranked last with relative weight $(57.75 \%)$.

Table 5. The arithmetic means and standard deviations of the degree of marital compatibility arranged in descending order according to the arithmetic means according to the fields of study

\begin{tabular}{cccccc}
\hline Number & Dimension & $\begin{array}{c}\text { arithmetic } \\
\text { mean }\end{array}$ & $\begin{array}{c}\text { standard } \\
\text { deviations }\end{array}$ & $\begin{array}{c}\text { relative } \\
\text { weight }\end{array}$ & Rank \\
\hline 1 & Personal compatibility & 2.48 & 0.85 & $\% 62$ & 1 \\
2 & Social compatibility & 2.47 & 0.74 & $\% 61.75$ & 2 \\
3 & Financial compatibility & 2.31 & 0.79 & $\% 57.75$ & 5 \\
4 & Compatibility with children & 2.32 & 0.72 & $\% 58$ & 4 \\
5 & Family conflicts & 2.46 & 0.83 & $\% 61.50$ & 3 \\
& Accumulative average of marital compatibility & 2.41 & 0.74 & $\% 60.25$ \\
\hline
\end{tabular}

Second: Presenting the statements according to the fields in descending order.

The first dimension: Personal compatibility:

According to Table 6, the level of compatibility in this dimension ranged between (52.50-70.25\%), and all the statements came with a moderate degree except for statement (2) "I understand my partner's feelings from his facial expressions," which came first in the personal dimension with relative weight. (70.25\%) and with a high degree of compatibility. Statement (4) "I adopt the method of dialogue and discussion with my partner" came in the last place with relative weight $(52.50 \%)$.

Table 6. The arithmetic mean, standard deviation, and relative weight of the first dimension statements

\begin{tabular}{|c|c|c|c|c|c|}
\hline No. & Statement & $\begin{array}{l}\text { arithmetic } \\
\text { mean }\end{array}$ & $\begin{array}{c}\text { standard } \\
\text { deviations }\end{array}$ & $\begin{array}{l}\text { relative } \\
\text { weight }\end{array}$ & Rank \\
\hline 1 & Listening to my partner when he wants to talk & 2.35 & 1.22 & $\% 58.75$ & 7 \\
\hline 2 & Understanding my partner's feelings from his facial expressions & 2.81 & 1.19 & $\% 70.25$ & 1 \\
\hline 3 & I feel sufficient attention from my life partner & 2.17 & 1.15 & $\% 54.25$ & 9 \\
\hline 4 & I adopt the style of dialogue and discussion with my partner & 2.10 & 1.05 & $\% 52.50$ & 10 \\
\hline 5 & I openly accept constructive criticism from my partner & 2.70 & 1.14 & $\% 67.50$ & 3 \\
\hline 6 & I have common goals with my life partner & 2.39 & 1.30 & $\% 59.75$ & 6 \\
\hline 7 & I consider myself happy in my marriage & 2.71 & 1.14 & $\% 67.75$ & 2 \\
\hline 8 & Agree with my partner on how I spend the time & 2.53 & 1.29 & $\% 63.25$ & 5 \\
\hline 9 & Be sure to continue our married life & 2.71 & 1.22 & $\% 67.75$ & 2 \\
\hline 10 & My partner feels happy just being together & 2.59 & 1.18 & $\% 64.75$ & 4 \\
\hline 11 & $\begin{array}{l}\text { I express my negative feelings in front of my partner without } \\
\text { hesitation }\end{array}$ & 2.18 & 1.17 & $\% 54.50$ & 8 \\
\hline
\end{tabular}

The second dimension: social compatibility:

According to Table 7, this dimension' level ranged between (50.50 - 67.75\%), where all the statements came with a moderate degree of compatibility. The statement (6) "manage my time in a way that allows me performing my family responsibilities" came first with relative weight (67.75\%), while Statement (1) "Participate with my partner in social events" ranked last, with relative weight (50.50\%).

Table 7. The arithmetic means standard deviation, and relative weight of the second-dimension statements

\begin{tabular}{|c|c|c|c|c|c|}
\hline No. & Statement & $\begin{array}{l}\text { arithmetic } \\
\text { mean }\end{array}$ & $\begin{array}{c}\text { standard } \\
\text { deviations }\end{array}$ & $\begin{array}{l}\text { relative } \\
\text { weight }\end{array}$ & Rank \\
\hline 1 & I participate in social events with my partner. & 2.02 & 1.06 & $\% 50.50$ & 6 \\
\hline 2 & I understand the social role of my life partner & 2.31 & 1.13 & $\% 57.75$ & 5 \\
\hline 3 & I make sure to submit the duty to my partner's family & 2.61 & 1.16 & $\% 65.25$ & 3 \\
\hline 4 & I refuse to interfere with others in my family affairs & 2.65 & 1.13 & $\% 66.25$ & 2 \\
\hline 5 & Take care of my partner's reputation in his absence and presence & 2.53 & 1.06 & $\% 63.25$ & 4 \\
\hline 6 & $\begin{array}{l}\text { manage my time in a way that allows performing my family } \\
\text { responsibilities }\end{array}$ & 2.71 & 1.06 & $\% 67.75$ & 1 \\
\hline
\end{tabular}


The third dimension: financial compatibility:

According to Table 8, the level in this dimension ranged between $(54.50-68.25 \%)$, where all the statements came with a moderate degree of compatibility, and statement (1) "I and my partner were exposed to financial difficulties and were exceeded" ranked first with relative weight (68.25\%), While statement (2) "I plan with my life partner where should we spend our money?" came last, with relative weight (54.50\%).

Table 8. The arithmetic mean, standard deviation, and relative weight of the third-dimension statements

\begin{tabular}{|c|c|c|c|c|c|}
\hline No. & Statement & $\begin{array}{c}\text { arithmetic } \\
\text { mean }\end{array}$ & $\begin{array}{c}\text { standard } \\
\text { deviations }\end{array}$ & $\begin{array}{l}\text { relative } \\
\text { weight }\end{array}$ & Rank \\
\hline 1 & My partner and I ran into financial hardship, and it got over. & 2.73 & 1.14 & $\% 68.25$ & 1 \\
\hline 2 & "I plan with my life partner, where should we spend our money? & 2.18 & 1.17 & $\% 54.50$ & 6 \\
\hline 3 & We discuss the decisions related to finance & 2.20 & 1.02 & $\% 55$ & 4 \\
\hline 4 & Together we face the financial crises we are experiencing & 2.24 & 1.17 & $\% 56$ & 3 \\
\hline 5 & My partner knows the importance of saving for the future very well & 2.28 & 1.11 & $\% 57$ & 2 \\
\hline 6 & Together we make sure that the expenses are only for necessity & 2.19 & 1.10 & $\% 54.75$ & 5 \\
\hline
\end{tabular}

The fourth dimension: compatibility with children:

According to Table 9, the level in this dimension ranged between $(52.50-69.50 \%)$, where all the statements came with a moderate degree of compatibility, and statement (2) "We are keen to satisfy the psychological needs of children" came at the first place with relative weight (69.50\%) While statement (7) "I agree with my partner on the way to deal with children" came last, with relative weight (52.50\%).

Table 9. The arithmetic mean, standard deviation, and relative weight of the fourth dimension statements

\begin{tabular}{|c|c|c|c|c|c|}
\hline No. & Statement & $\begin{array}{c}\text { arithmetic } \\
\text { mean }\end{array}$ & $\begin{array}{c}\text { standard } \\
\text { deviations }\end{array}$ & $\begin{array}{c}\text { relative } \\
\text { weight }\end{array}$ & Rank \\
\hline 1 & We teach our children how to make decisions & 2.35 & 1.10 & $\% 58.75$ & 3 \\
\hline 2 & We are keen to satisfy the psychological needs of children & 2.78 & 1.13 & $\% 69.50$ & 1 \\
\hline 3 & We develop our children's self-reliance & 2.17 & 1.15 & $\% 54.25$ & 7 \\
\hline 4 & I pay attention to my children's health. & 2.47 & 1.08 & $\% 61.75$ & 2 \\
\hline 5 & we develop the religious side of our children. & 2.18 & 1.16 & $\% 54.50$ & 6 \\
\hline 6 & We allow our children to express their opinion freely & 2.22 & 1.06 & $\% 55.50$ & 5 \\
\hline 7 & We have an agreement on how to deal with our children & 2.10 & 1.05 & $\% 52.50$ & 8 \\
\hline 8 & we make sure to follow our children's education & 2.31 & 0.97 & $\% 57.75$ & 4 \\
\hline
\end{tabular}

The Fifth Dimension: Family conflicts:

According to Table 10, this field's level ranged between $(52.50-71.75 \%)$, which indicates that all the statements came with a moderate and high degree of compatibility. Statement (4) came: "I am not satisfied with my partner's dealings with my family members" in First place with relative weight (71.75\%) and a high level. Statement (1) "Annoyed that my partner spends most of his time outside the home" ranked second with relative weight (70.75\%) and with a high degree, while statement (3) "I do not get The love and friendliness that I want from my life partner "ranked last, with relative weight (52.50\%).

Table 10. The arithmetic mean, standard deviation, and relative weight of the fifth dimension statements

\begin{tabular}{|c|c|c|c|c|c|}
\hline No. & Statement & $\begin{array}{l}\text { arithmetic } \\
\text { mean }\end{array}$ & $\begin{array}{c}\text { standard } \\
\text { deviations }\end{array}$ & $\begin{array}{l}\text { relative } \\
\text { weight }\end{array}$ & Rank \\
\hline 1 & Annoyed that my partner spends most of his time outside the home & 2.83 & 1.20 & $\% 70.75$ & 2 \\
\hline 2 & I don't listen sufficiently when we fight & 2.18 & 1.17 & $\% 54.50$ & 6 \\
\hline 3 & I don't get the love and respect that I want from my partner & 2.10 & 1.05 & $\% 52.50$ & 7 \\
\hline 4 & $\begin{array}{l}\text { I am not satisfied with my partner's dealings with my family } \\
\text { members }\end{array}$ & 2.87 & 1.10 & $\% 71.75$ & 1 \\
\hline 5 & I think that my husband is Less efficient than other husbands & 2.78 & 1.16 & $\% 69.50$ & 3 \\
\hline 6 & My partner always makes me angry & 2.26 & 1.16 & $\% 56.50$ & 4 \\
\hline 7 & we always have fights due to my partner's usage of social media & 2.22 & 1.06 & $\% 55.50$ & 5 \\
\hline
\end{tabular}

The second question: What is the relationship between marital compatibility and the accumulative average of students? 
To answer this question, the Pearson correlation coefficient was extracted between students 'scores on the two measures of marital compatibility and the accumulative average of the study sample, as shown in Table 11.

Table 11. Pearson correlation coefficient for the relationship between students' scores on the marital compatibility scale and the Accumulative average of the study sample

\begin{tabular}{cc}
\hline & Accumulative average \\
\hline the correlation coefficient $(\mathrm{R})$ & -0.103 \\
Statistical significant & 0.078 \\
Number & 293 \\
\hline
\end{tabular}

Table 11 shows that the value of the correlation coefficient between marital compatibility and the accumulative average was $(-0.103)$, which is a negative correlation that is not statistically significant at the level of significance $(\alpha<0.05)$.

The third question: Are there statistically significant differences in the level of marital compatibility among students due to the variable of gender (males, females)? To find out if there are differences in the level of the marital compatibility scale dimensions attributed to gender variable, use the (t) test, where Table 12 shows the averages, standard deviations, and $(\mathrm{T})$ test' results.

Table 12. ( $t$ ) test results for the differences between the mean scores of the two sexes on the instrument dimensions

\begin{tabular}{|c|c|c|c|c|c|}
\hline Dimensions & Gender & arithmetic mean & standard deviations & (t) value & Significance \\
\hline \multirow{2}{*}{ personal compatibility } & Males & 2.34 & 0.87 & 1.974 & 0.053 \\
\hline & Females & 2.55 & 0.84 & & \\
\hline \multirow{2}{*}{ Social compatibility } & Males & 2.33 & 0.76 & 2.342 & $0.023^{*}$ \\
\hline & Females & 2.54 & 0.72 & & \\
\hline \multirow{2}{*}{ Financial compatibility } & Males & 2.17 & 0.78 & 2.016 & 0.045 \\
\hline & Females & 2.37 & 0.78 & & \\
\hline \multirow{2}{*}{ Compatibility with children } & Males & 2.23 & 0.74 & 1.586 & 0.118 \\
\hline & Females & 2.37 & 0.72 & & \\
\hline \multirow{2}{*}{ Family conflicts } & Males & 2.31 & 0.82 & 2.144 & $0.033^{*}$ \\
\hline & Females & 2.53 & 0.83 & & \\
\hline \multirow{2}{*}{ Total marital compatibility scale } & Males & 2.28 & 0.75 & 2.125 & $0.036^{*}$ \\
\hline & Females & 2.48 & 0.74 & & \\
\hline
\end{tabular}

$*_{\alpha}>0.05$

Table 12 shows that the value of (t) for the marital compatibility scale was (2.125) with statistical significance ( $\alpha$ $<0.05)$. According to the table, it is evident that the average scores for females are higher than the average scores for males. In the social compatibility dimension, the value was $(t=2.342)$ with statistical significance $(\alpha<0.05)$. As the table shows, females' average scores are higher than the average of males' scores. As for the dimension of family conflicts, it reached a value of $(t=2144)$ with a statistical significance $(\alpha<0.05) .0 .05)$, and it is clear from the table that the average scores for females are higher than the average scores for males. Regarding the other dimensions, no significant differences were shown between the sexes.

The fourth question: Are there statistically significant differences in the degree of marital compatibility attributed to the variable of the number of family members?

To answer this question, One Way ANOVA was applied, as shown in Table 13.

Table 13. The results of the analysis of variance of the average of the sample individuals' estimates on the marital compatibility scale attributable to the family members

\begin{tabular}{ccccccc}
\hline Variable & Variance & $\begin{array}{c}\text { Total } \\
\text { squares }\end{array}$ & $\begin{array}{c}\text { Freedom } \\
\text { degree }\end{array}$ & $\begin{array}{c}\text { Average of } \\
\text { squares }\end{array}$ & (t) value & $\begin{array}{c}\text { statistical } \\
\text { significance }\end{array}$ \\
\hline Marital & Between groups & 0.863 & 2 & 0.431 & & \\
compatibility & Within groups & 161.106 & 290 & 0.556 & 0.777 & 0.461 \\
& Total & 161.969 & 292 & & & \\
\hline
\end{tabular}


Table 13 shows no statistically significant differences in the averages of the sample members 'estimates on the marital compatibility scale attributed to the variable of the number of family members.

The fifth question: Are there statistically significant differences in the degree of marital compatibility attributed to the variable of monthly income? To answer this question, we applied the One Way ANOVA, as it showed in Table 14

Table 14. The results of the analysis of variance of the average of the sample individuals' estimates on the marital compatibility scale, the monthly income variable

\begin{tabular}{ccccccc}
\hline Variable & Variance & $\begin{array}{c}\text { Total } \\
\text { squares }\end{array}$ & $\begin{array}{c}\text { Freedom } \\
\text { degree }\end{array}$ & $\begin{array}{c}\text { Average of } \\
\text { squares }\end{array}$ & $(\mathrm{t})$ value & $\begin{array}{c}\text { statistical } \\
\text { significance }\end{array}$ \\
\hline \multirow{2}{*}{ Marital } & Between groups & 0.930 & 2 & 0.465 & & \\
compatibility & Within groups & 161.039 & 290 & 0.555 & 0.837 & 0.434 \\
& Total & 161.969 & 292 & & & \\
\hline
\end{tabular}

Table 14 shows no statistically significant differences in the averages of the sample estimates on the marital compatibility scale attributed to the variable of monthly income.

The sixth question: Are there statistically significant differences in the degree of marital compatibility due to the variable of marriage duration?

To answer this question, One Way ANOVA was applied.

Table 15. The results of the analysis of variance of the average of the sample individuals' estimates on the marital compatibility scale, the duration of marriage variable

\begin{tabular}{|c|c|c|c|c|c|c|}
\hline Variable & Variance & $\begin{array}{c}\text { Total } \\
\text { squares }\end{array}$ & $\begin{array}{c}\text { Freedom } \\
\text { degree }\end{array}$ & $\begin{array}{c}\text { Average of } \\
\text { squares }\end{array}$ & (t) value & $\begin{array}{c}\text { statistical } \\
\text { significance }\end{array}$ \\
\hline \multirow{3}{*}{$\begin{array}{c}\text { Marital } \\
\text { compatibility }\end{array}$} & Between groups & 2.792 & 2 & 1.396 & & \\
\hline & Within groups & 159.177 & 290 & 0.549 & 2.543 & 0.080 \\
\hline & Total & 161.969 & 292 & & & \\
\hline
\end{tabular}

Table 15 shows no statistically significant differences in the averages of the sample estimates on the marital compatibility scale attributed to the variable of the duration of the marriage.

\subsection{Discussion of the Results}

The results showed that the level of marital compatibility for married student ranged between $(57.75-62 \%)$, and they were all positive and with a moderate degree of compatibility, as the researcher believes that this result is due to the presence of a level of emotional maturity and the ability to distinguish matters by controlling emotions and expressing them in a balanced manner, far from being reckless, because the couples who are socially and emotionally mature can positively interact and deal with others. According to the researcher's point of view, the degree of compatibility does not reach a high degree is a result of the multiplicity of married students' abilities to deal with the psychological pressures they are exposed to within the context of the study and the requirements of marital life that they are going through and addiction to work, the struggle between meeting the needs of their families and the requirements of university studies. Moreover, the work pressures of married couples do not end because it requires intellectual and physical abilities. This study's results agree with Abbas and Fateel's study (2019), which indicates that students have a medium level of psychological compatibility. It contradicts with the study of Sahu and Singh (2014) and the Sharman study (2007), which showed that the level of marital compatibility was high.

Furthermore, the results showed that there is a negative correlation between marital compatibility and the accumulative average, and this can be explained by the fact that the accumulative average is not affected only by compatibility, but there are other influencing factors such as motivation, enthusiasm, effort, and perseverance. Also, this result may be attributed to the fact that married students face many familial burdens imposed on them, which are characterized by the requirements of the family and children, work pressures among married people and the lack of management skills, and giving the body sufficient time to rest and relax, moreover, married student keep thinking about how to meet requirements of their families. The conflict they face regarding the needs of their families and fulfilling the requirements of university studies and their jobs.

The results indicated that there are statistically significant differences attributed to the gender variable and a 
statistical significance $(\alpha<0.05)$ in favor of females over males in the level of marital compatibility. The researcher attributes this result to the fact that males face many factors that help to decline their compatibility, including psychological, familial and social, and economic. The main reason may be the lack of understanding of the nature of the husband's tasks and his economic conditions. It should be noted that the familial burdens imposed on the married student keep him thinking remains how to fulfill the requirements of his family and provide them with the proper life within this difficult lifetime. Their feelings of negligence towards children and family play a role in increasing pressure on them, which will create psychological pressures for the married student, that will reflect negatively on their family in general and their marital compatibility in particular. This study contradicts the study of (Al-khatabeyh, 2015) and (Al'amoudy, 2001) since these studies indicate statistically significant differences in marital compatibility attributed to the gender variable and in favor of males over females. And Tawfiq's study (2015) indicated that there were no significant differences between husbands and wives.

The results also showed no differences in the level of marital compatibility attributed to variables of family members, monthly income, and the duration of the marriage. Where the researcher attributes this result to the fact that married students are individuals who chose their life partners without interference from family members, and that these married students have adapted their marital life to the lifestyle of the husband or wife, they are the most capable of achieving compatibility in marital relations.

This may also be due to the nature of the family upbringing within the Jordanian society, which makes them similar to behavioral and social norms. Therefore, their lives become mutual and easier, in addition to families' focus on creating feelings of sympathy in spouses and calming their tension and pressures they face. Consequently, a level of self- familial and academic regulation will be created inside them. This study's results are consistent with the (Al-khtabeyah, 2015) Study, which indicated that there are no differences in the level of marital compatibility due to the variable of family size. Al-Amoudi study (2001) indicated no statistically significant differences in marital compatibility due to the variable of monthly income. On the other hand, the same results contradict with the study of Al-khatabeyh (2015), in terms of the presence of differences in the level of compatibility due to the variable of monthly income in favor of those with high incomes, as well as, the study of Al-Amoudi (2001) which indicated the existence of statistically significant differences in marital compatibility due to the variable of the number of children and the duration of marriage variable.

\section{Recommendations}

Based on the results of the current study, several recommendations may be given:

$>$ Conduct training workshops to improve their performance and enhance marital compatibility.

$>$ Provide moral and material support for married students to meet their needs and their personal and familial needs.

$>$ Enhance the feeling of interacting positively with others and avoiding harmful familial and social activities that would disrupt marital relations.

$>$ Conducting other studies similar to this study on married individuals from different environments and regions and considering new variables.

\section{References}

A Dictionary of the Arabic Language. (1984). Dictionary of Psychology. Cairo: General Authority for Emiri Press Affairs.

Abbas, F., \&, Al-Asboul, K. (2019). The level of psychological compatibility and its relationship to some variables among the Ahlia University students in the Kingdom of Bahrain. Journal of Arts and Humanities, 2, 3 .

Abu Ghazaleh, S. (2008). The effectiveness of guidance in reality for improving marital compatibility between spouses. Psychological Studies, 18(2), 333-370.

Ahmed, S. (2015). The impact of women's jobs on marital compatibility: a case study of female military workers at Families Military Hospital in Omdurman (Unpublished MA thesis). El-Neelain University, Khartoum, Sudan.

Al-Amoudi, Y. (2001). Marital compatibility and its relationship to self-affirmation and its connection to some variables among married people in the Makkah region (Unpublished MA Thesis). Umm Al-Qura University, Makkah Al-Mukarramah, and Kingdom of Saudi Arabia. 
Al-Dahri, S., \& Al-Kubaisi, W. (1999). General Psychology. Irbid: Al-Kindi Publishing House.

Al-Harhasha, S. (2019). Jordanians Youth fears and their Relationship to Some Variables. Journal of Social Sciences (COES\&RJ-JSS), 8(4), 594-610. https://doi.org/10.25255/jss.2019.8.4.594.610

Al-Hasani, A. (2016). Familial Security: Concepts, Constraints, and Con Constituents strains (a field study in the city of Sana'a). Al-Andalus Journal for the Humanities and Social Sciences, 15(12), 163-231.

Al-Hindawi, M. (2011). Social support and its relationship to the level of happiness with the quality of life of the physically disabled in the Gaza governorates (Published MA Thesis). Al-Azhar University, Gaza, Palestine.

Al-Horany, A., Hassan, S., \& Bataineh, M. (2013). A review on factors affecting marital adjustment among parents of autistic children and gender effects. Life Science Journal, 10(1), 400-405.

Al-Jamaan, S. (2018). Marital compatibility and its relationship to the wife's perception of family responsibilities. The 9th International Academic Scientific Conference "Contemporary Trends in the Social, Human and Natural Sciences", 17-18 July 2018, Istanbul, Turkey.

Al-Kalhout, A. (2011). A comparative study of the psychosocial compatibility of the children of female and non-working women workers in private institutions in Gaza City (Published MA Thesis). Islamic University, Gaza, Palestine.

Al-Kandari, A. (1992). Family Psychology. Kuwait: Al Falah Library.

Al-Khateeb, Y. (2015). Elements of compatibility in marital life and its relationship to social factors: A study on a sample of husbands working in public schools in northern Jordan. Studies, Social Sciences, 42(2), 371-389. https://doi.org/10.12816/0019859

Al-Khouli, S. (2016). Family and family life. Alexandria: University Knowledge House.

Al-Maslamani, M. (2004). Marriage and the Family. Alexandria: Modern University Office.

Al-Razi, M. (1988), Mukhtar Al-Sahih. Beirut: Lebanon Library.

Al-Sayed, A. (1993). The level of self-concept, psychological compatibility, and its relationship to high school students' reflective and impulsive behavior. Unpublished MA thesis, Ain Shams University, Cairo, Egypt.

Al-Shahoumi, A. (1989) Psychological adjustment among the disabled: a study in adaptation psychology. Journal of New Education, 48, 68-95.

Al-Tahan, M. (1996). Principles of mental health. Dubai: Dar Al-Qalam for Publishing and Distribution.

Badawi, A. (1993). Islam and human psychological compatibility. Hoda Al-Islam Journal, 20(2), 1-14.

Chen, Z., Tanaka, N., Uji, M., Hiramura, H., Shikai, N., Fujihara, S. \& Kitamura, T. (2007). The role of personalities in the marital adjustment of Japanese couples. Social Behavior and Personality: An International Journal, 35(4), 561-572. https://doi.org/10.2224/sbp.2007.35.4.561

Dahri, S. (2008). Marital compatibility and its relationship to some variables among married teachers in Jordan. Culture and Development, 8(27), 1-18.

Daoud, A. (1988). Mental health and compatibility. Baghdad: Ministry of Education.

Desouki, M. (1986). Marital compatibility. Unpublished Ph.D. thesis, Zagazig University, Zagazig, Egypt.

Desouky, N. (1996). The causal model of the relationship between social support and the stress of life events and mental health in divorced women. Journal of Psychology, 39, 44-58.

Hashem, S. (1990). A study of some factors determining the style of family decision-making. Journal of the College of Education, 11(5), 265-312.

Jayaswal, S. (1989). Foundation of educational psychology. New Delhi: Arnold Heinemann Publishers.

Judge, A. (1994). Psychological compatibility from an Islamic perspective. Member Islam Magazine, 4, 36.

Kelly, L. (2000). Children's adjustment in conflicted marriage and divorce. A decade review of research. Journal of the American Academy of Child and Adolescent Psychiatry, 39(8), 963-973. https://doi.org/10.1097/00004583-200008000-00007

Khalil, M. (1999). The Psychology of Marital Relationships. Cairo: Quba House for Printing, Publishing, and Distribution.

Mahmoud, A. (2006). Marital compatibility in its relationship to some personality factors and emotional intelligence. Journal of the College of Education, 60, 54-110. 
Mansour, S. (2006). Psychological and social compatibility among secondary school students living in Rafah governorate's hot spots and its relationship to personality traits. Unpublished MA Thesis, Al-Quds University, Palestine.

Mehdi, S. (2012). Psychological burnout and its relationship to marital compatibility among intermediate and secondary school teachers. Unpublished MA thesis, University of Algiers, Algeria.

Minnotte, K. (2004). Marital happiness among dual-earner couples: The effects of work and family factors. Ph. D. Dissertation- Utah State University, Logan, Utah.

Morsi, S. (2008). Marital Dysfunctions: Causes and Consequences - Prevention and Treatment. Cairo: ENRAC House for Printing, Publishing, and Distribution.

Nasser, I. (2011). Educational Sociology. Beirut: Dar Al-Jeel Printing and Publishing.

Parmar, S. (2014). Mental Health and Marital Adjustment among Working and Non-Working Women. The International Journal of Indian Psychology, 1(4), 64-69. https://doi.org/10.25215/0104.008

Patterson, S. (1992). Theories of Counseling and Psychotherapy (translated by Hamed Abdulaziz Al-Feki). Kuwait: Dar Al-Qalam for Publishing and Distribution.

Peleg, O. (2008). The relation between differentiation of self and marital happiness: What can be learned from married people throughout life? The American Journal of Family Therapy, 36(5), 388-401. https://doi.org/10.1080/01926180701804634

Presser, H. (2000). Nonstandard work schedules and marital instability. Journal Marriage \& Family, 62(1), 93-110. https://doi.org/10.1111/j.1741-3737.2000.00093.x

Saghir, C. (2014). Representations of marital compatibility and its relationship to methods of marital treatment and marital disputes. Journal of the Humanities and Social Sciences, 16, 345-371.

Sahu, K., \& Singh, D. (2014). Mental health and marital adjustment of working and non-working married women. International Journal of Advancement in Education and Social Sciences, 2(2), 24-28.

Sharman, S. (2007). Communication between spouses and their relationship to marital compatibility from the viewpoint of Yarmouk University employees. Unpublished MA thesis, Yarmouk University, Irbid, Jordan.

Singh, R., Thind, S., \& Jaswal, S. (2006). Assessment of marital adjustment among couples concerning women's educational level and employment status. Journal the Anthropologist, 8(4), 259-266. https://doi.org/10.1080/09720073.2006.11890974

Soliman, S. (2005). Marital compatibility and family stability from an Islamic, psychological, and social perspective. Cairo: The World of Books.

Stone, E., \& Shackelford, T. (2007). Marital happiness. In R. F. Baumeister, \& K. D. Vohs (Eds.), Encyclopedia of social psychology (pp. 541- 544). Thousand Oaks, CA: Sage.

Sufyan, N. (2004). The Manual on Personality and Psychological Counseling. Cairo: Petrac Publishing and Distribution.

Sussman, M., \& Steinmetz, S. (2013). Handbook of marriage and the family. New York: Plenum Press.

Tawfiq, A. (2015). Some Characteristics of Compatibility, Positive Social Behavior, and its Relationship to Marital Compatibility. Journal of Psychological Counseling, 42, 31-64.

Zahran, H. (1982). Mental health and psychotherapy. Cairo: The World of Books.

\section{Copyrights}

Copyright for this article is retained by the author(s), with first publication rights granted to the journal.

This is an open-access article distributed under the terms and conditions of the Creative Commons Attribution license (http://creativecommons.org/licenses/by/4.0/). 